\title{
Research on Teaching Reform of Internet Plus Automotive Service Engineering
}

\author{
YU Xiuhua ${ }^{1, a}$, SHAN Yuhao ${ }^{2, b,}$ SHAN Xiliang ${ }^{3, c}$ \\ ${ }^{1}$ Baicheng Normal University, Baicheng, 137000, China \\ ${ }^{2}$ Sichuan University, Chengdu, 610000, China \\ ${ }^{3}$ Training Unit of 63850 Troops, Baicheng, 137000, China \\ aemail: 365834088@qq.com, bemail:1104318987@qq.com, ${ }^{\mathrm{C} e m a i l}: 252455911 @ q q . c o m$
}

Keywords: Internet Plus, Teaching Reform of Automobile Service Engineering,Teacher, Student

\begin{abstract}
Under the Internet Plus environment, the teaching reform of automobile service engineering has been carried out in an all-round way, which has made up the gap between the training of automotive service engineering professionals and the needs of the social market. This paper briefly analyzes the important significance of the teaching reform of Internet Plus automobile service engineering, discusses the existing problems of traditional teaching activities, and discusses the reform scheme of Internet Plus automobile service engineering teaching.
\end{abstract}

\section{Introduction}

The era of "Internet Plus" first appeared at the Mobile Internet Expo in 2012. The chairman of analysis International defined the concept of the "Internet Plus" era as "all traditional services should be changed in conjunction with the Internet". The proposal for promoting the innovative Development of China's economy and Society clearly points out that "Internet Plus" refers to the use of information technology to connect the Internet with various traditional industries, thus creating an innovative ecology. Premier Li Keqiang put forward the "Plan of Action on Internet Plus at the 12th National people's Congress of China." on July of the same year, The State Council issued the State Council's guidance on actively promoting "Internet Plus", which pushed forward the new strategy and exploration of "Internet Plus" and gradually created a new normal of efficiency. Under the influence of the "Internet Plus" era, The teaching mode of automobile service engineering has also changed, which has effectively promoted the development of automobile service engineering teaching.

\section{Significance of Teaching Reform of Internet Plus Automotive Service Engineering}

Carrying out the teaching reform of Internet Plus automobile service engineering will help to make up for the deficiency of the traditional teaching mode. Guiding students to learn independently "Automotive Electronics and Electronic Control system", "Automotive Construction", "Automotive Service Engineering", "Automotive maintenance Engineering", "Automotive Marketing", "Automotive Insurance and claims", "Automotive Service Information system", "Automobile Manufacturing Technology" "study", "Automotive Theory", "Automobile Detection and Diagnostic Technology", "Automobile hydraulic and pneumatic transmission", "New Automobile Technology", etc. Improve students' professional skills in automotive after-sales service, auto trade service, automotive technology service, automobile logistics service, automobile maintenance service, auto finance and insurance service, automobile production and modification, automobile design and vehicle evaluation, etc. In addition, in the course of teaching reform of Internet Plus automobile service engineering, teachers will help our school to improve the network platform, build a good information base, and increase the construction of digital campus. Realizing full coverage of WiFi, upgrading MOOC hardware technology, uploading all kinds of courseware resources and video lectures by using Internet Plus technology, enabling students to study independently online, discuss and download resources online without limitation of time and place. Access to information and 
interactive teaching to assist students to complete their learning tasks[1].

\section{Problems Existing in Traditional Automobile Service Engineering Teaching activities}

In the past, the teaching contents of automobile service engineering have deviated from the demand for talents in the social market, and there are generally backward teaching ideas and training bases. Due to the influence of traditional teaching concepts, teachers pay too much attention to the explanation of theoretical knowledge and neglect the cultivation of students' practical ability and service consciousness. Teachers do not combine knowledge transmission with Internet technology, which is not conducive to improving teaching efficiency. Secondly, most schools do not set up training bases on campus. In addition, under the traditional teaching mode, the cooperation between the school and the enterprise is still in the shallow development state, the enterprises outside the school often only value the skilled students, To a certain extent, students who lack practical experience are refused to provide a broad practical platform, so most of the students with low practical skills can only participate in shallow practice activities[2].

\section{Teaching Reform Scheme of Internet Plus Automobile Service Engineering}

Innovating Teaching thought and Reforming Classroom Teaching. At present, Courses in Automotive Service Engineering include Automotive Electronics and Electronic Control Systems, Automotive Construction, Automotive Service Engineering, Automotive maintenance Engineering, Automotive Marketing, Automotive Insurance and claims, Automotive Service Information system, Automotive, Manufacturing Technology, Automotive Theory, Automobile Detection and diagnosis Technology, Automobile hydraulic and pneumatic Transmission, New Automobile Technology, and involving Engineering Application Software, Advanced Mathematics, Mechanical drawing, Mechanics of Materials, Automobile Design, Theoretical Mechanics, fundamentals of Mechanical Design, Microcomputer principles and Interface techniques, Traffic and Transportation Engineering, Thermodynamics and Engine principles, Electronic Technology, and other theoretical knowledge and skills. In carrying out all courses teaching, teachers should pay attention to combining the requirements of market posts for talents, cut them down, and avoid duplication of knowledge content[3]. We should gradually strengthen the practical teaching activities such as "Automobile Inspection and diagnosis Technology", "Automobile Manufacturing Technology" and "New Automobile Technology", so as to optimize the automotive service engineering system in an all-round way. In addition, teachers should innovate their teaching ideas and concepts. Adhere to the idea of "people-oriented", optimize classroom teaching methods with the help of Internet Plus technology, comprehensively guide students to learn the frontier knowledge and dynamics of automobile service engineering, the important role of cognitive practical teaching activities and the future professional nature. In order to effectively improve students' enthusiasm for learning, strengthen students' practical skills, maintain students' learning motivation, establish students' working spirit and sense of responsibility and service. Teachers can first use multimedia courseware to make students realize that a car is a four-wheeled self-propelled vehicle designed mainly for passenger transport, usually driven by an internal combustion engine using volatile fuel. The modern car is made up of about 14000 parts. The utility model comprises several structural and mechanical systems, including a steel body with space for passengers and storage, arranged on a chassis or steel frame, an internal combustion engine for a car, which is powered by a transmission, a steering and braking system to control the movement of the car, and a motor vehicle. Electronic systems, including batteries, alternators and other devices. Other important systems include fuel, exhaust, lubrication, cooling, Suspension and tire system, etc. This can help students to master the basic knowledge of automobile electrical equipment construction. Then, the teacher should guide students to set up the automobile simulation analysis system, identify the automobile parts, Finally, it can guide students to bring into full play their innovative consciousness and maintenance skills in practice, and master the assembly process of automobile skillfully, so as to effectively promote the development of students' innovative skills and the legal system of practical education[4]. 
The goal of Internet Plus automotive service engineering teaching reform is to train innovative practical talents to meet the needs of social market development. Based on this background, teachers should attach importance to optimizing the content of practical teaching and strengthening students' ability to use their brains. Teachers can adjust the previous syllabus appropriately, delete the old practical activities, and add the inquiring and innovative practical teaching contents on the basis of the traditional practical teaching activities. In order to cultivate students' spirit of inquiry, stimulate students' creative potential and improve students' comprehensive practical ability, teachers should attach importance to the reform of traditional teaching methods. Students are regularly organized to participate in various practical activities in order to cultivate students' ability to practice knowledge and explore, to improve students' practical skills, and to construct a perfect evaluation system of automobile service engineering teaching[5].

In the process of constituting the teaching evaluation system of automobile service engineering, teachers should do a good job in three aspects: first, according to the teaching nature of the school to determine the evaluation index of teachers' classroom teaching quality; second, The evaluation index of classroom teaching quality should be quantified according to the measurement standard of classroom teaching quality. In general, two evaluation systems, teaching evaluation and curriculum evaluation, should be paid attention to when investigating the evaluation index of classroom teaching quality. The evaluation content of print advertisement design classroom teaching mainly involves the evaluation of teaching method, teaching form, teaching content, teaching attitude and teaching effect, while the course evaluation mainly includes teaching reference materials, textbooks, teaching materials, etc. Courseware, questions asked in class, after-class homework, teaching items and final examination contents, etc; third, a progressive index system should be constructed after quantifying all the evaluation indicators. It should be noted that the curriculum evaluation system is a kind of effective interactive mode which is shared and progressively progressive in time, and its composing system mainly includes student evaluation. Peer evaluation and teacher self-evaluation. Among them, the student evaluation system is composed of two groups of students and graduates, the peer evaluation involves the peer evaluation of their peers and the peer evaluation of outside schools. Teachers' self-evaluation must be carried out strictly according to the index. In order to run the evaluation system of classroom teaching quality, we should pay attention to six major work links, that is, setting up the goal, establishing the quality standard of the important teaching link, doing well the measurement and statistics work, and completing the evaluation. In order to ensure the objectivity and fairness of the evaluation results, the quality of classroom teaching should be improved according to five principles[6]. They are to guide teachers to improve the teaching quality of print advertising design, objective, fair, fair, reasonable and scientific principles, to ensure teachers' collective participation and to receive information widely. To promote the principle of combining teaching theory with practical teaching work, and to combine objective reality with the subjective will of teachers and students. It should be noted that teachers should regard students as the source of information when collecting information on the evaluation of classroom teaching quality. To listen to the students' opinions, to formulate a more scientific and comprehensive evaluation system and to carry out various evaluation work, we should not only attach importance to the current teaching effect of teachers, but also objectively evaluate the teaching contents chosen by teachers. Teaching methods and teaching attitude can improve teachers' classroom teaching quality.

Strengthening the Construction of Practical Training Base and Improving Students' Comprehensive Ability. To build a modern realization base, we must do a good job in two aspects. On the one hand, teachers should cooperate with our school to build laboratories to promote the integration of theoretical and practical teaching. In the process of establishing laboratories, teachers should adhere to the following three principles:

First, to ensure the sharing of experimental equipment and resources. Teachers can strengthen the cooperation between their schools and outside schools, realize the sharing of teaching resources on campus, and ensure the mutual borrowing of all experimental equipment, thereby expanding the scope of students' experiments and knowledge and forming knowledge. The sharing of teaching 
resources and practical activities.

Second, through the cooperation of schools and enterprises to build modern laboratories. From the development point of view, the market and enterprises are the first to come into contact with new automobile technologies, not schools, and it is very difficult for colleges and universities to purchase all new equipment in a short period of time. In order to build the laboratory shared by the school and enterprise, the enterprise can provide the experiment equipment for the school, expand the practice platform of the students, and employ the high-quality technical talents with the help of the school as the talent training base to promote the mutual benefit of both the school and the enterprise[7].

Third, adhere to the principle of "opening to the outside world" and perfect the technical service system. Schools should provide the most advanced experimental equipment from various means, build up the automobile maintenance bases in schools, and carry out paid services to the outside world. In this way, the utility value of the experimental equipment in the school can be effectively promoted, the students' ability to use knowledge in practice can be strengthened, and the students' professional service consciousness can be strengthened.

On the other hand, it is necessary to comprehensively strengthen the construction of the training base inside and outside the school, quantify the special function of the training base, and do a good job in three steps. First, the teacher should cooperate with the students to establish a special training room for automobile service engineering, and listen to the suggestions of the students. According to the students' personality and learning needs, set up practical training areas, such as automobile construction area, automobile service area, automobile maintenance area, automobile marketing area, painting color area, automobile disassembly area, automobile service information platform, etc. Secondly, teachers should pay attention to strengthening the construction of comprehensive training base, promoting the close combination of teaching, research, practical training and social service, etc. This can not only assist students to understand and use theoretical knowledge quickly, but also strengthen students' ability to practice knowledge, point out the direction of scientific research for students, and train students to meet the needs of social market development. Teachers should extensively open up practical training bases outside school, guide students to go out of school, visit enterprises and factories, understand the internal structure and market demand of enterprises, participate in on-the-job practice activities and accumulate work experience, so as to continuously improve students' vocational skills[8].

Strengthening Cooperation between Schools and Enterprises. Schools should attach importance to further strengthening cooperation between schools and enterprises, Invite the staff of cooperative enterprise to guide students to master automobile electronics and electronic control system, automobile construction, automobile service engineering, automobile maintenance engineering, auto marketing, auto insurance and claim settlement, auto suit. The practical operation flow of professional knowledge, such as information system, etc., The teachers should listen to the suggestions of the enterprise staff, cooperate with them to perfect the teaching plan, set up diversified practical courses, and strengthen the students' ability of hands-on brain work and knowledge conversion. Revise the talent training mechanism and rationally allocate the proportion of theoretical credits and practical credits.

\section{Conclusion}

To sum up, carrying out the teaching reform of Internet Plus automobile service engineering will help to make up for the deficiency of traditional teaching mode, assist students to learn theoretical knowledge well, and improve students' professional practical skills and service consciousness. Teachers should combine the demands of market posts on talents, simplify and simplify, optimize classroom teaching methods with the help of Internet Plus technology, and comprehensively guide students to learn the frontier knowledge and dynamics of automobile service engineering. The important role and future professional nature of cognitive practical teaching activities; assisting our school to set up modern laboratories and strengthen the construction of practical training bases inside and outside the school; strengthening cooperation between schools and enterprises; setting up 
diversified practical courses. We will continue to improve the training mechanism of high-quality professional service personnel.

\section{References}

[1]YE LV. Exploring the Model of German FH Applied Experiment Teaching through the Whole Process of Teaching[J].Journal of Zhejiang University of Science and Technology,2010(10).

[2]BAO Fanbiao. A Study on the Reform of Practical Teaching in the Course of Automobile Theory[J]. Value Engineering,2011(08).

[3]ZHOU Ping, SUN Yuedong, WANG Xiaoyan. Study on the Construction of Higher Vocational and Technical Education System and its Countermeasures[D].Journal of Kunming University of Science and Technology,2014(10).

[4]LIU Chunyue. Research and Practice of Innovative Talents Training System for Automobile Technical Service and Marketing Specialty in Higher Vocational Colleges[J].Ability and Wisdom,2013(11).

[5]WANG Xudong, DU Li, WANG Licun. Reform Thinking on the Teaching Mode of Production Practice for Automobile Service Engineering[J]. Science and Technology Innovation Herald, 2014(30).

[6]WANG Denggui, ZHANG Jingdong, QI Xuemei. Research on the Reform of Practice Teaching System for Automobile Service Engineering Specialty[J]. Experiment Science and Technology, 2014(4).

[7]NIE Yonghong, XU Yan, PANG Youxia. Research on the Teaching Reform of the Course of Automobile Service Engineering Foundation[J]. Journal of Changsha University,2015(2).

[8]ZHENG Limin, WEN Jinhai, LIU Shuwei. Research on Practical Teaching Reform of Automobile Service Engineering Specialty based on Engineering training[J]. Journal of Liaoning University of Technology(Social Science Edition),2014(5). 